\title{
Comparison the efficacy of pneumatic and holmium laser ureteroscopic lithotripsy for the treatment of ureteral stones: a retrospective observational study
}

\author{
Üreter taşları tedavisinde pnömatik ve holmium lazer taş kırıcıların karşılaştırılması: \\ retrospektif gözlemsel çalışma
}

Tuncer Bahçeci, Aykut Başer

Gönderilme tarihi:10.01.2022

Kabul tarihi:28.02.2022

\begin{abstract}
Purpose: To compare the efficacy and complications of holmium laser lithotripters and pneumatic lithotripters, the two most commonly used lithotripters in the endoscopic treatment of ureteral stones, at all ureteral levels.

Material and method: Retrospective data on 510 patients who had ureterorenoscopic lithotripsy performed by a single surgeon between January 2018 and 2021 were studied. Patients were divided into two groups: those who received a holmium laser lithotripter and those who received a pneumatic lithotripter. Demographic information, stone-free rates, double-j $(\mathrm{JJ})$ stent usage, JJ stent removal time, type of anesthesia, operation time, hospital stay, and complication rates were all examined.

Results: The patient numbers in the holmium laser and pneumatic groups were 265 and 245, respectively. The overall success rate in group 1 was found to be significantly higher than in group 2 (98.5\% percent vs $93.9 \%$ percent; $p=0.006)$. Group 1 had a significantly higher success rate in proximal ureteral stones $(94.4 \%$ percent vs $68.9 \%$ percent; $p=0.001$ ). Patients in group 1 had a significantly higher rate of not using any ureteral stent (29.8\% percent vs $17.6 \%$ percent; $p<0.001)$. There was no difference between the two groups in terms of mid-ureter and distal ureter stones, anesthesia type, operation time, hospital stay, JJ stent removal time, and complications.

Conclusion: For ureteral stones, ureterorenoscopic lithotripsy is the chosen therapeutic approach. The location of the stone in the ureter as well as the type of lithotripters used can have an impact on the outcome. Because of its great efficiency and lack of need for ureteral stents, holmium laser lithotripsy may be preferred for the treatment of proximal ureteral stones.
\end{abstract}

Key words: Holmium laser, pneumatic lithotripsy, ureteral stones.

Bahceci T, Baser A. Comparison the efficacy of pneumatic and holmium laser ureteroscopic lithotripsy for the treatment of ureteral stones: a retrospective observational study. Pam Med J 2022;15:648-655.

Öz

Amaç: Üreter taşlarının endoskopik tedavisinde en sık kullanılan taş kırıcılar olan holmium lazer ve pnömatik taş kıııcıların tüm üreter seviyelerinde etkinlik ve komplikasyonlarını karşılaştırmak.

Gereç ve yöntem: Ocak 2018-2021 tarihleri arasında, tek cerrah tarafından üreterorenoskopik taş kırma uygulanan 510 hastanın verileri retrospektif olarak incelendi. Taş kırıcı cinsine göre lazer taş kıııcı (Grup 1) ve pnömatik taş kırıcı (Grup 2) olarak iki gruba ayrıldı. Taşın üreter içerisindeki lokalizasyonuna göre üreter proksimal, mid ve distal olmak üzere 3 bölüme ayrıldı. Demografik veriler, tam taşsızlık oranları, double-j (JJ) stent kullanımı, JJ stent çıkarıma süresi, anestezi yöntemi, operasyon süresi, hastanede kalış süresi ve komplikasyon oranları araştıııldı.

Bulgular: Hasta sayısı sırasıyla Grup 1'de 265, Grup 2'de 245 saptandı. Genel başarı oranı Grup 1'de \%98,5, Grup 2'de \%93,9 saptandı ve Grup 1'de istatiksel olarak daha başarılı bulundu $(p=0,006)$. Proksimal üreter taşlarında başarı oranı Grup 1'de anlamlı olarak daha yüksek bulundu (\%94,4'e karşı $\% 68,9 ; p=0,001)$. Stent kullanılmadan sonlandırılan vaka sayısı Grup 1'de istatiksel olarak daha yüksek saptandı (\%29,8'e karşı \%17,6; $p<0,001)$. Orta üreter ve distal üreter taşları, anestezi tipi, ameliyat süresi, hastanede kalış süresi, JJ stent çıkarma süresi ve komplikasyonlar açısından iki grup arasında fark bulunmadı.

Sonuç: Üreter taşları tedavisinde en sık tercih edilen yaklaşım üreterorenoskopik taş kırma yöntemidir. Taşın üreter içerisindeki lokalizasyonu ve taş kıııının cinsi başarıyı etkilemektedir. Proksimal üreter taşları tedavisinde, yüksek etkinlik ve daha az üreteral stent ihtiyacı nedeniyle holmium lazer taş kıııcı tercih edilebilir.

Anahtar kelimeler: Holmium lazer, pnömatik taş kırıcı, üreter taşları.

Bahçeci T, Başer A. Üreter taşları tedavisinde pnömatik ve holmium lazer taş kırıııların karşılaştırıması: retrospektif gözlemsel çalışma Pam Tıp Derg 2022;15:648-655.

Tuncer Bahçeci, Speacilist M.D. Sanliurfa Training and Research Hospital, Sanliurfa, Turkey, e-mail: tuncerbahceci@gmail.com (https://orcid. org/0000-0002-3178-9169) (Corresponding Author)

Aykut Başer, Assoc. Prof. Bandırma Onyedi Eylül University Faculty of Medicine, Department of Urology, Balıkesir, Turkey, e-mail: aqut85@ windowslive.com (https://orcid.org/0000-0003-0457-512X) 


\section{Introduction}

After urinary system infections and prostate illnesses, urinary system stone disease is the third most frequent pathological condition in the field of urology [1]. While $5-10 \%$ of the population in Europe and North America may get kidney stones during their lives, the rate in Asia is greater [2]. Its incidence was reported to be 11.1 percent in our country [3].

In urinary system stone disorders, ureteral stones account for a significant portion of everyday urology practice [2]. For the treatment of ureteral stones, there are a variety of options. Ureteroscopic lithotripsy (URS), shock-wave lithotripsy (SWL), laparoscopic/ open ureterolithotomy, and percutaneous nephrolithotomy are some of the procedures available [4]. URS has become the primary chosen treatment procedure in many centers due to the development of ancillary equipment and its high stone-free rate. [5]. During the URS, a variety of energy sources can be used. There are four types of lithotripters: ultrasonic, electrohydraulic, pneumatic, and laser. Holmium: yttrium-aluminum-garnet (YAG) laser lithotripter (LL) and pneumatic lithotripter (PL) are the most commonly used lithotripters today $[6,7]$. Many studies in the literature compare $\mathrm{LL}$ and $\mathrm{PL}$ in terms of stone-free rates, safety, complications, and cost. Although some studies show no difference between the two groups, many studies show that LL is more effective. In conclusion, there are still controversial results between the two groups. As a result, we conducted a retrospective review of the clinical data of 510 patients who underwent PL and LL in our clinic in order to contribute to the literature.

\section{Materials and methods}

\section{Study type and ethical approval}

This study was a retrospective observational study and approval was obtained from the Harran University Clinical Research Ethics Committee.

\section{Patients and data collection}

A total of 601 patients underwent ureterolithotripsy by a single surgeon at Sanliurfa training and research hospital in Sanliurfa, an endemic city for stone disease, between January $1,2018-2021$. This retrospective observational study included 510 patients who met the study criteria. The exclusion criteria were as follows; patients under 18 years of age, patients whose stones were removed with forceps without using a lithotripter, who had simultaneous ureter and kidney stone due to URS + PNL (percutaneous nephrolithotomy) performed in the same session, who had a push back with the effect of fluid before reaching the stone, who underwent a $\mathrm{JJ}$ stent or nephrostomy tube application due to perioperative purulence formations, pregnancy, patients who underwent URS due to forgotten encrusted JJ stents, and whose stones could not be reached due to lower end involvement or mid-ureteral narrow segment. Urine culture and kidney function test, and abdominopelvic non-contrast computed tomography (CT) was performed in all patients before the procedure. The stone diameter was accepted as the largest measured linear dimension (transverse or craniocaudal section). Patients with growth in urine culture were included in the study after urinary tract infection was treated. Ureteral stones were divided into three anatomical groups as upper, middle, and lower, according to their location. Accordingly, stones located on the sacroiliac bone were evaluated as upper ureteral stones, stones located in the same plane with the sacroiliac bone were considered middle ureter stones, and stones located under the sacroiliac bone were considered as lower ureteral stones.

Patients were divided into two groups according to the type of lithotripter used in endoscopic ureteral stone treatment as Group 1; Holmium: yttrium-aluminum-garnet (YAG) laser lithotripter (LL) ( $n=265 ; 52 \%)$ and Group 2 ; pneumatic lithotripter ( $P L)(n=245 ; 48 \%)$. URS was considered successful after the stonefree status was determined by post-treatment imaging methods. All patients were evaluated with non-contrast computed tomography or abdominal radiography at one month postoperatively. It was accepted as a success if the image showed that the stone disappeared completely or the residual stone in the urinary tract was less than $2 \mathrm{~mm}[8,9]$.

Patients' age, gender, stone laterality and localization, stone size, anesthesia method, operation time, postoperative double $\mathrm{J}(\mathrm{JJ})$ stent placement, duration of hospital stay, success rate (stone-free), and data on complication 
observation were collected. Complications were classified according to the modified Clavien Dindo grading system. The efficacy and complications of Group 1 and Group 2 were compared.

All patients included in the study signed an informed consent form.

\section{Surgical technique}

All operations in this study were performed by a single surgeon. Sterile urine cultures of all patients were examined before the procedure. Following the anesthesia administration, 1 $\mathrm{g}$ of cefazolin intravenous was administered to all patients for prophylaxis. The choice of anesthesia type was determined according to the preference of the anesthesiologist. All procedures were performed with a 9.5 Fr distal tip semi-rigid ureteroscope (Karl Storz, Tuttlingen, Germany) with a 0.035-inch guidewire. After reaching the stone, holmium laser (Sphinx Junior, Germany; with energies ranging from 0.6 to $1.2 \mathrm{~J}$ and pulses from 8 to $15 \mathrm{~Hz}$.) or pneumatic lithotripter (Elmed, Turkey; with a 3.3-Fr probe and a pressure of 2 bars) was used for stone fragmentation according to the possibilities of the surgeon. The stones were fragmented into particles smaller than $2 \mathrm{~mm}$ to increase the probability of spontaneous falling. Auxiliary instruments such as a stone cone or ureteral basket catheter were not used. According to the surgeon's decision, no catheter was applied to some patients after stone fragmentation, while a $5 \mathrm{Fr}$ ureteral catheter or $4.8 \mathrm{Fr}$ double $\mathrm{J}$ stent was applied to the rest of the patients. The following criteria determined the decision to apply a catheter: prolonged operation time (>60 minutes), increased residual stone discharge, narrow or edematous ureterovesical junction, and mucosal/edema formed by the stone or the lithotripter. After the operation was completed, a 14-18 Fr Foley catheter was placed in the bladder and removed on the same day or the next day.

\section{Statistical analysis}

Statistical analysis was performed using IBM SPSS Statistics for Windows, Version 22.0 (IBM Corp., Armonk, NY, USA). Continuous or categorical data were presented as mean \pm standard deviation, frequency, the percentile. The normal distribution of continuous data was tested with the Kolmogorov-Smirnow test. In the comparison of continuous data between groups, Student's t-test was used if the data showed normal distribution, and the Mann Whitney-U test was used if it did not show normal distribution. The $X^{2}$ test (or the Fisher exact test) was used to compare categorical data. Cases where $p<0.05$ were considered significant.

\section{Results}

Between January 1, 2018, and January 1, 2021, 510 patients underwent endoscopic ureteral stone treatment. The mean age of the patients was $37.7 \pm 12.9$ years. $74.3 \%$ of the patients were male, and $25.7 \%$ were female. $48.8 \%$ of the interventions were performed on the right side, while $51.2 \%$ were on the left. Of the endoscopic ureteral stone treatments, $79 \%$ were under spinal anesthesia, $21 \%$ were under general anesthesia, and the mean surgical procedure duration was $40.4 \pm 18.4$ minutes. $52 \%$ of laser and $48 \%$ of pneumatic lithotripsy were used as lithotripsy methods.

When the patients are grouped as Group 1 and Group 2 according to the stone lithotripter type, their clinical and demographic characteristics are shown in Table 1. No difference was found between the groups regarding gender, stone laterality, localization, size, and number. It was observed that PL was applied more frequently in the younger age group.

When the perioperative and postoperative characteristics of the groups were examined, considering postoperative catheterization, it was found that there was no necessity for a ureteral catheter in patients in Group 1, significantly more than those in Group 2 (29.8\%, vs $17.6 \%$, $p<0.001$, respectively). While $59.8 \%$ of the postoperative stent usage was JJ stent usage, an external ureteral catheter was applied to $16.2 \%$ of the patients; no stent was applied to $24 \%$ of the patients. Also, the $5 \mathrm{Fr}$ ureteric catheter usage rate was $25.3 \%$ in the $\mathrm{PL}$ group and $7.9 \%$ in the LL group. No difference was found between the two groups regarding the type of anesthesia, operation time, hospital stay, JJ stent removal time, and complications (Table 2).

When the general complications related to ureterorenoscopy were analyzed, ClavienDindo grade II complications were seen in 
Table 1. Clinical and demographic characteristics

\begin{tabular}{|c|c|c|c|c|}
\hline & & $\begin{array}{l}\text { Group } 1 \\
(n=265 ; 52 \%)\end{array}$ & $\begin{array}{l}\text { Group } 2 \\
(n=245 ; 48 \%)\end{array}$ & $p$ \\
\hline \multicolumn{2}{|c|}{ mean age \pm SD (year) } & $39.2 \pm 12.4$ & $36.1 \pm 13.2$ & 0.001 \\
\hline \multirow{2}{*}{ Gender } & Male n (\%) & $202(76.2)$ & $177(72.2)$ & \multirow{2}{*}{0.304} \\
\hline & Female n (\%) & $63(23.8)$ & $68(28.8)$ & \\
\hline \multirow{2}{*}{$\begin{array}{l}\text { Stone } \\
\text { laterality }\end{array}$} & Right n (\%) & $135(50.9)$ & $114(46.5)$ & \multirow{2}{*}{0.319} \\
\hline & Left n (\%) & $130(49.1)$ & $131(53.2)$ & \\
\hline \multirow{3}{*}{$\begin{array}{l}\text { Stone } \\
\text { location }\end{array}$} & Upper n (\%) & $54(20.4)$ & $45(18.4)$ & \multirow{3}{*}{0.824} \\
\hline & Middle n (\%) & $61(23)$ & $60(24.5)$ & \\
\hline & Distal n (\%) & $150(56.6)$ & $140(57.1)$ & \\
\hline \multicolumn{2}{|c|}{ Stone diameter, $\mathrm{mM}$} & $8.2 \pm 2.9$ & $8.8 \pm 3.8$ & 0.124 \\
\hline \multicolumn{2}{|c|}{ Number of stones, $\mathrm{n}$} & $1.0 \pm 0.1$ & $1.0 \pm 0.1$ & 0.073 \\
\hline
\end{tabular}

Table 2. Operative and postoperative data

\begin{tabular}{|c|c|c|c|c|}
\hline & & $\begin{array}{l}\text { Group } 1 \\
(n=265 ; 52 \%)\end{array}$ & $\begin{array}{l}\text { Group } 2 \\
(n=245 ; 48 \%)\end{array}$ & $p$ \\
\hline \multirow{2}{*}{ Type of anesthesia } & Spinal n (\%) & $218(82.3)$ & $185(75.5)$ & \multirow{2}{*}{0.061} \\
\hline & General n (\%) & $47(17.7)$ & $60(24.5)$ & \\
\hline \multicolumn{2}{|c|}{ Mean operation time \pm SD $(\min )$} & $41.5 \pm 20.5$ & $40.3 \pm 16.8$ & 0.652 \\
\hline \multicolumn{2}{|c|}{ Mean hospital stay \pm SD (days) } & $1.3 \pm 1.5$ & $1.2 \pm 1.6$ & 0.339 \\
\hline \multirow{3}{*}{ Catheter placement } & None n (\%) & $79(29.8)$ & $43(17.6)$ & \multirow{3}{*}{$<0.001$} \\
\hline & JJ stent n (\%) & $165(62.3)$ & $140(57.1)$ & \\
\hline & Ureteral catheter n (\%) & $21(7.9)$ & $62(25.3)$ & \\
\hline \multicolumn{2}{|c|}{ Mean JJ stent removal time \pm SD (Days) } & $21.7 \pm 18.1$ & $19.5 \pm 19.1$ & 0.056 \\
\hline \multirow{2}{*}{ Ureterorenoscopy result } & Stone Free n (\%) & $261(98.5)$ & $230(93.9)$ & \multirow{2}{*}{0.006} \\
\hline & Pusch Back n (\%) & $4(1.5)$ & $15(6.1)$ & \\
\hline \multirow[t]{2}{*}{ Complications } & Yes n (\%) & $8(3)$ & $10(4.1)$ & \multirow{2}{*}{0.516} \\
\hline & No n $(\%)$ & $257(97)$ & $235(95.9)$ & \\
\hline
\end{tabular}

16 patients, including $2.54 \%(n=13)$ patients with febrile urinary tract infection and $0.58 \%$ $(n=3)$ patients with postoperative colic pain. These complications were treated with medical treatment. Distal ureteral avulsion (ClavienDindo grade IVa) was observed in one patient during access of the ureteral orifice with a ureterorenoscope and was followed up with a $\mathrm{JJ}$ stent application. It is not included in any stone crusher group because it is during the accession. Ureteral perforation (ClavienDindo grade IIIb) occurred in one patient while advancing proximally with the ureterorenoscopy after fragmentation with pneumatic lithotriptor, and open primary repair was performed. Apart from these, no major complications were observed in any of the patients.
The overall success rate was $98.5 \%$ in Group 1 and $93.9 \%$ in Group 2. When both groups were compared, Group 1 was statistically more successful than Group $2(p=0.006)$. The success rate in proximal ureteral stones was found to be $94.4 \%$ in Group 1 and $68.9 \%$ in Group 2. In the mid-ureter and distal ureter, the success rates were found to be $100 \%$ and $99.3 \%$ in Group 1 and $98.3 \%$ and $100 \%$ in Group 2, respectively. As a result of the comparison of the groups as per the stone localizations, it was determined that the factor affecting the success was caused by the proximal ureter stones $(p=0.001)$, and there was no statistically significant difference between the mid-ureter and distal ureter stones between the two methods (respectively, $p=0.496, p=1.000$ ). The results are shown in Table 3. 
Table 3. Ureterorenoscopy results between groups according to stone localization

\begin{tabular}{lllll}
\hline Stone location & Ureterorenoscopy result & $\begin{array}{l}\text { Group 1 } \\
\text { (n=265; 52\%) }\end{array}$ & $\begin{array}{l}\text { Group 2 } \\
\text { (n=245; 48\%) }\end{array}$ & $\boldsymbol{p}$ \\
\hline \multirow{2}{*}{ Upper } & Stone Free n (\%) & $51(94.4)$ & $31(68.9)$ & $\mathbf{0 . 0 0 1}$ \\
& Pusch Back n (\%) & $3(5.6)$ & $14(31.1)$ & \\
Middle & Stone Free n (\%) & $61(100)$ & $59(98.3)$ & 0.496 \\
\multirow{2}{*}{ Distal } & Pusch Back n (\%) & $0(0)$ & $1(1.7)$ & \\
& Stone Free n (\%) & $149(99.3)$ & $140(100)$ & \multirow{2}{*}{000} \\
Total & Pusch Back n (\%) & $1(0.7)$ & $0(0)$ & $\mathbf{0 . 0 0 6}$ \\
\hline
\end{tabular}

\section{Discussion}

Ureteral stones are among the diseases that require treatment most frequently in the field of urology. The Nephrolithiasis Guideline of the European Association of Urology (EAU) recommends SWL and URS as the two most popular treatment modalities [8]. However, SWL has become the most preferred treatment modality by urologists because of the high need for a second treatment in SWL and the advancements in endourology in parallel with the technology, making URS better, stone-free, faster, and more reliable [10-12].

PL is used very frequently, especially in developing countries, due to its low purchasing cost. It was first used clinically in 1992 [13]. In this method, a ballistic effect is created by transmitting compressed dry air pressure to the probe tip, and the stones are fragmented [14]. Pneumatic lithotripters do not cause thermal damage to the ureter since high heat is not generated during this process. However, the stone migration rate is higher than other lithotripters due to the ballistic effect $[15,16]$.

Today, LL is the gold standard among ureterorenoscopy lithotripters because of its flexibility and high success rate in all stone types $[4,17]$. Due to its high cost, availability is difficult, especially in economically developing countries. The holmium laser fragments the stones into very small pieces with its photothermal effect. If care is not taken during the fragmentation, there is a risk of thermal damage to the ureteral mucosa with a direct thermal effect, but the stone migration effect is very low since it does not have a ballistic effect [18].
According to the EAU guidelines, it is known that the overall success rate of $\mathrm{PL}$ in ureteral stones is $90 \%$ [4]. In a study conducted in our country in 2014 , the overall success rate was $89.9 \%$ [19]. In their study involving pediatric ureteral stones, Yucel et al. [20] found a PL success rate of $84.3 \%$ in their study. In the studies of Manohar et al. [21] and Hong et al. [5], it was found to be $84 \%$ and $93.5 \%$, respectively. In our study, while the overall success rate of PL was similar to that of Hong and Park [5], the success rate was higher than in other studies. According to the literature, the reason for the high overall success rate in our study is that the number of patients in the mid and distal ureteral stones was considerably higher than the number of patients in the proximal ureter, and the stone migration rate is low in stones at this level. The success rate of $\mathrm{PL}$ in proximal ureteral stones varies between $75 \%$ and $90.5 \%$ in the literature $[5,19,22-26]$. In our study, we found a lower success rate in the proximal ureter compared to the literature. The reasons for this result are the high rate of pushback in the proximal ureter and the lack of stone migration prevention equipment.

In the literature, the success rate of $\mathrm{LL}$ in proximal ureteral stones ranges between $81.8 \%$ and $96 \%$ [26-30]. In this study, we found that LL was superior to $\mathrm{PL}$ in the treatment of proximal ureteral stones, consistent with the literature. The most important reason for this is that the stone migration (SM) rate was statistically higher in Group 2. In the study conducted by Razzaghi et al. [7], the rate of SM was found as $17.9 \%$ in the $\mathrm{PL}$ group and $0 \%$ in the $\mathrm{LL}$ group. Tipu et al. [31] found the rate of SM in LL and $\mathrm{PL}$ was $16 \%$ and $4 \%$, respectively. In the study of Manohar et al. [21], the rate of SM was 
determined as LL and PL, 24\% and 16\%, but there was no statistically significant difference between the two groups. In a study in 2009 in which LL was performed by using a stone cone basket catheter, the rate of SM was found to be $0 \%$ [32]. In the study of Bastawisy et al. [33] in 2011, PL was performed on 20 patients using a stone cone basket, and SM was not detected. The high rate of SM in PL in our study may be due to the stone size in the proximal ureter being smaller than in other studies or due to not using any basket catheter. However, when both groups were compared, the rate of SM was statistically lower in LL, which is consistent with the literature.

Both LL and PL are very effective methods for mid-ureter and distal ureteral stones. The success rate of $\mathrm{PL}$ was $93.8 \%$ and $96.9 \%$ in the study of Hong and Park [5] and $85 \%$ and $98.4 \%$ by Akdeniz et al. [19] in the mid and distal ureters, respectively. The LL success rate was $96 \%$ and $92.2 \%$ by Akdeniz et al. [19] and $96 \%$ by Solvado et al. [34] in the distal ureter. In our study, the success rate in the mid-ureter and distal ureter was compatible with the literature.

Routine postoperative stenting is still controversial today. Many authors argue that stenting increases morbidity after uncomplicated URS. The advantages of postoperative stent use are that it prevents ureteral edema or acute renal colic due to stone fragments, facilitates the spontaneous fall of stone fragments, and prevents the development of postoperative urosepsis. The most important disadvantage is that it increases labor loss and costs due to the necessity of secondary invasive intervention. Besides, it impairs the patient's quality of life by causing stent-related symptoms such as dysuria, pollakiuria, pain, and hematuria. However, it is practiced by all urologists in the case of urethral injury, in patients with solitary kidneys, and in patients with a large residual stone burden [8]. In our study, while $59.8 \%$ of the patients were applied JJ stents and $16.2 \%$ were applied external ureteral catheters, $24 \%$ did not have any stent. While the use of JJ stent was $86.2 \%$ in the study of Khoder et al. [9], JJ stenting was routinely applied to all patients $(100 \%)$ in a prospective study of 50 patients published in 2020 [35]. In our study, when the use of stent was compared between the two groups, it was seen that statistically fewer postoperative catheters were applied in patients who underwent $L L$ than those who underwent PL (70.2\% and $82.4 \%)$. The reasons for this are the higher rate of pushback and higher mucosal/ edema formed by the stone or the lithotripter fragments in the PL group. Also, the rate of $5 \mathrm{Fr}$ ureteric catheter usage was $25.3 \%$ and $7.9 \%$ in the PL group and LL group, respectively. This is since the stones are dusty after laser lithotripsy and partially larger fragments are seen after PL, and it is used more in the PL group to prevent acute renal colic.

The complication rate associated with ureteroscopic lithotripsy ranges from $9 \%$ to $25 \%$ [8]. Minor complications are renal colic, haematuria, urinary infection, mucosal injuries, and urinary extravasation, while major complications are ureteral perforation and avulsion. In a study published in 2014, ClavienDindo grade III, IV, and V complication rates were reported as $0.5 \%, 0.1 \%$, and $0.02 \%$, respectively [36]. In the study of Geavlete et al. [37], the mucosal damage rate was $1.5 \%$, the ureteral perforation rate was $1.7 \%$, and the ureteral avulsion rate was $0.1 \%$. Our overall complication rates are consistent with the literature. Studies are comparing the complication rates of laser and pneumatic lithotripters in the literature. In our study, minor complications were found in $3 \%$ of LL and $4.1 \%$ of PL patients. No significant difference was found between the two groups. Many studies support this in the literature [23, $25,26,38$. However, there are also studies in the literature indicating that lower complication rates are observed in LL [31, 39].

The main limitation of this study is that patients treated for ureteral stones cannot be randomized due to the principle of a retrospective observational study. In addition, there was no postoperative first day and long-term follow-up. Another limitation of our study was not being able to use stone density (Hounsfield Unit).

As a result, for ureteral stones, ureterorenoscopic lithotripsy is the chosen therapeutic approach. The location of the stone in the ureter as well as the type of lithotripters used can have an impact on the outcome. Because of its great efficiency and lack of need for ureteral stents, holmium laser lithotripsy may be preferred for the treatment of proximal ureteral stones.

Conflict of interest: No conflict of interest was declared by the authors. 


\section{References}

1. Silay MS, Kadıhasanoğlu M, Miroğlu C. Medical treatment and diet in urinary stone disease. Med Bull Sisli Etfal Hosp 2007;41:7-12.

2. Rabani SM, Rabani S, Rashidi N. Laser versus pneumatic lithotripsy with semi-rigid ureteroscope; a comparative randomized study. J Lasers Med Sci 2019;10:185-188. https://doi.org/10.15171/ jlms.2019.29

3. Muslumanoglu AY, Binbay M, Yuruk E, et al. Updated epidemiologic study of urolithiasis in Turkey. I: Changing characteristics of urolithiasis. Urol Res 2011;39:309314. https://doi.org/10.1007/s00240-010-0346-6

4. Türk C, Knoll T, Petrik A, et al. Urolithiasis. European Association of Urology Guidelines 2013.

5. Hong YK, Park DS. Ureteroscopic lithotripsy using swiss lithoclast for treatment of ureteral calculi: 12-years experience. J Korean Med Sci 2009;24:690694. https://doi.org/10.3346/jkms.2009.24.4.690

6. Torricelli FCM, Mazzucchi E, Danilovic A, Coelho RF, Srougi M. Surgical management of bladder stones: literature review. Rev Col Bras Cir 2013;40:227-233. https://doi.org/10.1590/s0100-69912013000300011

7. Razzaghi MR, Razi A, Mazloomfard MM, Taklimi GA, Valipour R, Razzaghi Z. Safety and efficacy of pneumatic lithotripters versus holmium laser in the management of ureteral calculi: a randomized clinical trial. Urol J 2013;10:762-766.

8. Preminger GM, Tiselius HG, Assimos DG, et al. 2007 Guideline for the management of ureteral calculi. Eur Urol 2007;52:1610-1631. https://doi.org/10.1016/j. eururo.2007.09.039

9. Khoder WY, Bader M, Sroka R, Stief C, Waidelich R. Efficacy and safety of Ho: YAG laser lithotripsy for ureteroscopic removal of proximal and distal ureteral calculi. BMC Urology: 2014;14:1-7. https://doi. org/10.1186/1471-2490-14-62

10. Leone NT, Garcia Roig M, Bagley DH. Changing trends in the use of ureteroscopic instruments from 1996 to 2008. J Endourol 2010;24:361-365. https://doi. org/10.1089/end.2009.0222

11. Rosemary F. Ureteroscopy overtakes SWL for ureteral stone treatment. Renal Urology News 2012;02.

12. Eisner BH, Kurtz MP, Dretler SP. Ureteroscopy for the management of the stone disease. Nat Rev Urol 2010;7:40-45. https://doi.org/10.1038/nrurol.2009.233

13. Denstedt JD, Eberwein PM, Singh RR. The Swiss Lithoclast: a new device for intracorporeal lithotripsy. J Urol 1992;148:1088-1090. https://doi.org/10.1016/ s0022-5347(17)36827-1

14. Schock J, Barsky RI, Pietras JR. Urolithiasis update: clinical experience with the Swiss Litho Clast. J Am Osteopath Assoc 2001;101:437-440.
15. Piergiovanni M, Desgrandchamps F, Cochand Priollet $B$, et al. Ureteral and bladder lesions after ballistic, ultrasonic, electrohydraulic, or laser lithotripsy. J Endourol 1994;8:293-299. https://doi.org/10.1089/ end.1994.8.293

16. Menezes P, Kumar PV, Tımoney AG. A randomized trial comparing lithoclast with an electrokinetic lithotripter in the management of ureteric stones. BJU Int 2000;85:2225. https://doi.org/10.1046/j.1464-410x.2000.00428.x

17. Lee J, Gianduzzo TRJ. Advances in laser technology in urology. Urol Clin North Am 2009;36:189-198. https:// doi.org/10.1016/j.ucl.2009.02.004

18. Zarrabi A, Gross AJ. The evolution of lasers in urology. Ther Adv Urol 2011;3:81-89. https://doi. org/10.1177/1756287211400494

19. Akdeniz E, İrkılata L, Demirel HC, et al. A comparison of efficacies of holmium YAG laser, and pneumatic lithotripsy in the endoscopic treatment of ureteral stones. Turk J Urol 2014;40:138-143. https://doi. org/10.5152/tud.2014.46548

20. Yucel S, Akin Y, Kol A, Danisman A, Guntekin E. Experience on semirigid ureteroscopy and pneumatic lithotripsy in children at a single center. World J Urol 2011;29:719-723. https://doi.org/10.1007/s00345010-0599-2

21. Manohar T, Ganpule A, Desai M. Comparative evaluation of Swiss LithoClast 2 and holmium: YAG laser lithotripsy for impacted upper-ureteral stones. J Endourol 2008;22:443-446. https://doi.org/10.1089/ end.2007.0288

22. Gunlusoy B, Degirmenci $T$, Arslan $M$, et al. Ureteroscopic pneumatic lithotripsy: is the location of the stone important in decision making? Analysis of 1296 patients. J Endourol 2008;22:291-294. https://doi. org/10.1089/end.2007.0160

23. Kassem A, Elfayoumy $H$, Elsayed W, Elgammal $M$, Bedair A. Laser and pneumatic lithotripsy in the endoscopic management of large ureteric stones: a comparative study. Urol Int 2012;88:311-315. https:// doi.org/10.1159/000336254

24. Sözen S, Küpeli B, Tunc L, et al. Management of ureteral stones with pneumatic lithotripsy: report of 500 patients. J Endourol 2003;17:721-724. https://doi. org/10.1089/089277903770802236

25. Aydemir H, Budak S, Hirik E, Kumsar Ş, Çelik O, Adsan Ö. Upper ureteral stone treatment: effectiveness and complications of holmium laser and pneumatic lithotripsy. J Clin Anal Med 2016;7:46-49. https://doi. org/10.4328/JCAM.3230

26. Irer B, Şen V, Erbatu O, et al. Comparison of efficacy and complications of holmium laser and pneumatic lithotripters used in the ureterorenoscopy treatment of proximal ureter stones, a multi-center study of society of urological surgery Aegean study group. J Urol Surg 2018;5:158-163. https://doi.org/10.4274/jus.2143 
27. Degirmenci T, Gunlusoy B, Kozacioglu Z, et al. Comparison of Ho: YAG laser and pneumatic lithotripsy in the treatment of impacted ureteral stones: an analysis of risk factors. Kaohsiung J Med Sci 2014;30:153-158. https://doi.org/10.1016/j.kjms.2013.08.007

28. Ilker Y, Ozgür A, Yazici C. Treatment of ureteral stones using Holmium: YAG laser. Int Urol Nephrol 2005;37:3134. https://doi.org/10.1007/s11255-004-6084-3

29. Bagley DH. Expanding the role of ureteroscopy and laser lithotripsy for treatment of proximal ureteral and intrarenal calculi. Curr Opin Urol 2002;12:277-280. https://doi.org/10.1097/00042307-200207000-00003

30. Jeon SS, Hyun JH, Lee KS. A comparison of Holmium: YAG laser with lithoclast lithotripsy in ureteral calculi fragmentation. Int J Urol 2005;12:544-547. https://doi. org/10.1111/j.1442-2042.2005.01087.x

31. Tipu SA, Malik HA, Mohhayuddin N, et al. Treatment of ureteric calculi--use of Holmium: YAG laser lithotripsy versus pneumatic lithoclast. J Park Med Assoc 2007;57:440-443.

32. Eisner BH, Dretler SP. Use of the Stone Cone for prevention of calculus retropulsion during holmium: YAG laser lithotripsy: case series and review of the literature. Urol Int 2009;82:356-360. https://doi. org/10.1159/000209372

33. Bastawisy M, Gameel T, Radwan M, Ramadan A, Alkathiri M, Omar A. A comparison of Stone Cone versus lidocaine jelly in the prevention of ureteral stone migration during ureteroscopic lithotripsy. Ther Adv Urol 2011;3:203-210. https://doi. org/10.1177/1756287211419551

34. Salvadó JA, Mandujano R, Saez I, et al. Ureteroscopic lithotripsy for distal ureteral calculi: comparative evaluation of three different lithotriptors. J Endourol 2012;26:343-346. https://doi.org/10.1089/ end.2011.0416

35. Rashid AO, Attar A, Mohammed KS, Fakhralddin SS, Abdulla LN, Buchholz N. Direct comparison of pneumatic and Ho: YAG laser lithotripsy in the management of lower ureteric stones. Urol Int 2020;104:765-768. https://doi.org/10.1159/000508419

36. De la Rosette J, Denstedt J, Geavlete P, et al. The clinical research office of the endourological society ureteroscopy global study: indications, complications, and outcomes in 11,885 patients. J Endourol 2014;28:131-139. https://doi.org/10.1089/ end.2013.0436

37. Geavlete P, Georgescu D, Niţă G, Mirciulescu V, Cauni V. Complications of 2735 retrograde semirigid ureteroscopy procedures: a single-centre experience. J Endourol 2006;20:179-185. https://doi.org/10.1089/ end.2006.20.179
38. Nour HH, Kamel Al, Elmansy $\mathrm{H}$, et al. Pneumatic vs laser lithotripsy for mid-ureteric stones: clinical and cost-effectiveness results of a prospective trial in a developing country. Arab J Urol 2020;18:181-186. https://doi.org/10.1080/2090598X.2020.1749800

39. Bapat SS, Pai KV, Purnapatre SS, Yadav PB, Padye AS. Comparison of holmium laser and pneumatic lithotripsy in managing upper-ureteral stones. J Endourol 2007;21:1425-1427. https://doi.org/10.1089/ end. 2006.0350

Ethical statements: This study was conducted with the approval obtained from the Harran University Clinical Research Ethics Committee of with a number 21.04.09 and the date February 15, 2021.

\section{Authors' contributions}

T.B. designed the study, data collection, literature search, manuscript writing, and final approval of the version to be published. A.B. drafted the manuscript, designed the figures, and verified the analytical methods and final approval of the version to be published. 